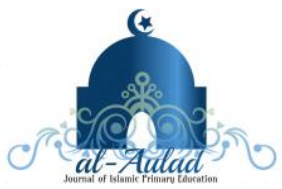

\title{
PENGGUNAAN MODEL LEARNING CELL TERHADAP HASIL BELAJAR SISWA MADRADAH
}

\author{
Anas Salahudin ${ }^{1}$, Novian Sukmawati ${ }^{1}$ \\ Jurusan Pendidikan Guru Madrasah Ibtidaiyah, UIN Sunan Gunung Djati, Bandung, Indonesia \\ anassalahudin@uinsgd.ac.id
}

Naskah diterima: 25 Desember, 2017, direvisi: 1 januari, 2018, diterbitkan: 31 Maret, 2018

\begin{abstract}
This study is based on theoretical study which states that the high of the students 'learning outcomes in IPS subjects is influenced by the students' responses to The Learning Cell model. The purpose of this research is to know: (1) Reality of student responses to The Learning Cell model; (2) The reality of their learning outcomes on IPS subjects of the subject of the proclamation of independence of the Republic of Indonesia; (3) Reality of student response relation to cooperative learning model of The Learning Cell type with their learning result in IPS subject. The method used is descriptive method. Data collection techniques with interviews, observation and dissemination of questionnaires and tests. The sample in this study were 22 students. Correlation analysis of both variables using product moment correlation technique, because both variables are normal distribution and regresinya linear. From the results of the analysis, it is known that students' responses to the cooperative learning model of The Learning Cell types fall into the high category with an average value of 3.97. The results of their study on IPS subjects included into the category enough with an average value of 65.54. There is a significant positive relationship between students' responses to the cooperative learning model of The Learning Cell type in relation to their learning outcomes on IPS subjects of the subject of the proclamation of independence of the Republic of Indonesia.
\end{abstract}

Keywords: cooperative learning, the learning cell, learning outcomes, social studies

\begin{abstract}
ABSTRAK
Penelitian ini bertolak pada kajian teori yang menyatakan bahwa tinggi rendahnya hasil belajar siswa pada mata pelajaran IPS salah satunya dipengaruhi oleh tanggapan siswa terhadap model The Learning Cell. Tujuan dari penelitian ini adalah untuk mengetahui: (1) Realitas tanggapan siswa terhadap model The Learning Cell; (2) Realitas hasil belajar mereka pada mata pelajaran IPS pokok bahasan proklamasi kemerdekaan Republik Indonesia; (3) Realitas hubungan tanggapan siswa terhadap model pembelajaran kooperatif tipe The Learning Cell dengan hasil belajar mereka pada mata pelajaran IPS. Metode yang digunakan adalah metode deskriptif. Teknik pengumpulan datanya dengan wawancara, observasi dan penyebaran angket dan tes. Sampel dalam penelitian ini sebanyak 22 orang siswa. Analisis korelasi kedua variabel menggunakan teknik korelasi product moment, karena kedua variabel berdistribusi normal dan regresinya linier. Dari hasil analisis, diketahui bahwa tanggapan siswa terhadap model pembelajaran kooperatif tipe The Learning Cell termasuk ke dalam kategori tinggi dengan nilai rata-rata 3,97. Adapun hasil belajar mereka pada mata pelajaran IPS termasuk ke dalam kategori cukup dengan nilai rata-rata 65,54. Terdapat hubungan positif yang signifikan antara tanggapan siswa terhadap model pembelajaran kooperatif tipe The Learning Cell hubungannya dengan hasil belajar mereka pada mata pelajaran IPS pokok bahasan proklamasi kemerdekaan Republik Indonesia.
\end{abstract}

Kata kunci: hasil belajar, mata pelajaran IPS, pembelajaran kooperatif, the learning cell 


\section{PENDAHULUAN}

Pendidikan merupakan sebuah proses yang dapat menjadikan manusia berkembang dalam hal potensi dirinya dan menjadikan manusia itu lebih dewasa. Proses dalam pendidikan yang dimaksud tidak terlepas dari kegiatan belajar, mengajar dan pembelajaran. Dalam pendidikan, kegiatan yang paling penting adalah proses belajar mengajar dan pembelajaran. Kedua proses tersebut memiliki keterkaitan satu sama lain. Berhasil tidaknya pencapaian tujuan pembelajaran banyak dipengaruhi oleh kualitas proses belajar mengajar yang dialami oleh siswa (Sutikno, 2009, hlm. 3).

Pendidikan mempunyai peran yang sangat penting dalam kehidupan manusia. Salah satu faktor yang mempengaruhi pendidikan ialah proses pembelajaran siswa di kelas. Untuk mencapai hasil pembelajaran yang baik, seorang guru harus dapat memilih model pembelajaran dan merencanakan strategi belajar yang tepat agar tujuan pembelajaran dan strategi belajar salah satunya bertujuan untuk meningkatkan hasil belajar siswa.

Salah satu faktor yang paling menentukan berhasilnya proses pembelajaran dalam kelas adalah model pembelajaran. Oleh karena itu, guru tidak hanya berfungsi sebagai orang dewasa yang bertugas profesional memindahkan ilmu pengetahuan dan menyalurkan ilmu pengetahuan yang dikuasainya kepada peserta didik, lebih dari itu guru harus memahami model apa yang harus disampaikan pada muridnya (Muhibbin Syah, 2000: hlm. 53).

Model pembelajaran kooperatif tipe The Learning Cell adalah salah satu cara dari pembelajaran kelompok, khususnya kelompok kecil. Dalam pembelajaran ini siswa diatur berpasang-pasangan. Salah satu diantaranya berperan sebagai tutor, fasiliator/pelatih ataupun konsultan. Orang yang kedua ini berperan sebagai siswa, peserta latihan ataupun seorang yang memerlukan bantuan.Setelah selesai, maka giliran peserta kedua untuk berperan sebagai tutor, fasiliator ataupun pelatih dan peserta pertama menjadi siswa ataupun peserta latihan. Model pembelajaran kooperatif tipe The Learning Cellmerupakan cara praktis untuk mengadakan pengajaran sesama siswa di kelas. Model pembelajaran ini juga memungkinkan guru untuk member tambahan bila dirasa perlu pada pengajaran yang dilakukan oleh siswa (Suprijono, 2009, hlm. 122).Proses mempelajari hal baru tentunya akan lebih efektif jika siswa dalam kondisi aktif, bukannya reseptif. Salah satu cara untuk menciptakan kondisi pembelajaran seperti ini adalah dengan menstimulir siswa untuk menyelidiki atau mempelajari sendiri materi pelajarannya.

Salah satu upaya untuk meningkatkan hasil belajar IPS pada siswa adalah dengan menerapkan model pembelajaran kooperatif (cooperative learning).Hal ini sejalan dengan pendapat Nadhifah (2009, hlm. 13) yang mengatakan bahwa pembelajaran kooperatif merupakan model pembelajaran yang dapat menimbulkan terjadinya interaksi antara siswa sehingga siswa lebih mudah menentukan dan memahami konsep-konsep yang sulit apabila siswa mendiskusikan permasalahan dengan temannya.

Berdasarkan studi pendahuluan didapat keterangan dari guru mata pelajaran IPS kelas $\mathrm{V}$, bahwa pembelajaran dengan menggunakan model pembelajaran kooperatif tipe The Learning Cellditanggapi secara positif oleh siswa. Hal ini dapat dilihat dengan adanya antusias ketika mengikuti pembelajaran. Tetapi di sisi lain khusus untuk pokok bahasan proklamasi kemerdekaan Republik Indonesia diperoleh informasi bahwa nilai rata-rata dari 22 orang siswa hasil belajarnya termasuk kategori rendah. Hal ini berdasarkan data sementara yaitu 5 orang siswa yang memperoleh nilai 7, 6 orang siswa yang memperoleh nilai 6,4 orang siswa yang memperoleh nilai 5 , dan 5 orang siswa yang memperoleh nilai 5,5. Berdasarkan data tersebut diperoleh nilai rata-rata 5,5.

Fenomena di atas menunjukan bahwa di kelas V MI Al-Misbah Bandung telah terjadi kesenjangan antara tingginya tanggapan siswa terhadap pembelajaran IPS yang 
menggunakan model pembelajaran kooperatif tipe The Learning Cell dengan rendahnya hasil belajar mereka pada mata pelajaran IPS pokok bahasan proklamasi kemerdekaan Republik Indonesia. Berdasarkan fenomena tersebut, permasalahan-permasalahan yang muncul adalah bagaimana proses pembelajaran IPS di kelas V MI Al-Misbah Bandung?. Bagaimana tanggapan siswa terhadap model pembelajaran kooperatif tipe The Learning Cell pokok bahasan proklamasi kemerdekaan Republik Indonesia? Bagaimana pula hasil belajar mereka pada mata pelajaran IPS pokok bahasan proklamasi kemerdekaan Republik Indonesia?

\section{METODOLOGI}

Metode yang digunakan dalam penelitian ini adalah metode deskriptif Moh Ali (1999, hlm. 120) menyatakan bahwa metode deskriptif digunakan untuk memecahkan atau menjawab permasalahan yang sedang berlangsung pada situasi sekarang. Adapun teknik pengumpulan data yang digunakan dalam penelitian ini, sebagai berikut:

1. Angket

Angket adalah alat untuk mengumpulkan dan mencatat data atau informasi, pendapat, dan paham dalam hubungan kausal (Zainal Arifin, 2013, hlm. 166). Dalam hal ini, angket digunakan untuk menggali data tentang tanggapan siswa terhadap model pembelajaran kooperatif tipe The Learning Cell dan hasil belajar mereka pada mata pelajaran IPS. Angket yang disebarkan sifatnya langsung yakni diberikan kepada responden dan tidak melalui orang lain. Bentuk angket ini adalah terstruktur, berisi pertanyaan maupun pertanyaan yang disertai sejumlah alternatif jawaban. Sedangkan alternatif yang dikembangkan akan disusun secara berjenjang ke dalam 5 option. Jika a=5, b=4, c=3, $\mathrm{d}=2$, dan $\mathrm{e}=1$. Dan jika item angket berorientasi negatif maka penyekorannya $\mathrm{a}=1, \mathrm{~b}=2$, $c=3, d=4$, dan $e=5$.

2. Tes

Tes adalah serentetan pertanyaan atau alat lain yang digunakan untuk mengukur keterampilan, pengetahuan, intelegensi, kemampuan atau hakikat yang dimiliki oleh individu atau kelompok (Suryana \& Priatna, 2009, hlm. 215). Tujuan tes ini adalah untuk memperoleh data tentang hasil belajar mereka dengan menggunakan model pembelajaran kooperatif tipe The Learning Cell pada mata pelajaran IPS pokok bahasan proklamasi kemerdekaan Republik Indonesia. Tes yang digunakan adalah tes objektif bentuk pilihan ganda.Pada tes objektif, kebenaran jawaban bersifat mutlak. Jawaban hanya mempunyai dua kemungkinan yaitu benar apabila pada sebuah butir soal siswa menjawab sesuai dengan kunci jawaban dan salah apabila siswa memilih jawaban yang tidak sesuai dengan kunci jawaban.Oleh karena kebenarannya bersifat pasti maka siswa memperoleh skor 1 (satu) bila menjawab benar, dan 0 (nol) apabila menjawab salah. Misalnya pada sebuah tes objektif yang terdiri dari 50 butir soal, siswa akan menjawab benar sebanyak 25 butir, maka akan memperoleh skor 25 (Purwanto, 2011: 188).

Setelah data dari kedua pokok permasalahan terkumpul maka langkah selanjutnya data tersebut dianalisis dengan tujuan untuk melihat sejauh mana keterkaitan atau hubungan dari kedua permasalahan di atas. Analisis data yang digunakan adalah analisis parsial. Analisis ini dilakukan terhadap dua variabel secara terpisah. Dalam hal ini tanggapan siswa terhadap model pembelajaran Kooperatiftipe The Learning Cell sebagai (variabel X), dan hasil belajar mereka pada mata pelajaran IPS pokok bahasan proklamasi kemerdekaan Republik Indonesia sebagai (variabel Y). 
Untuk mengetahui tanggapan siswa kelas V MI Al-Misbah Bandung terhadap penggunaan model pembelajaran kooperatif tipe The Learning Cell pada Mata Pelajaran IPS, dilakukan dengan menyebarkan angket kepada 22 responden. Pada awalnya instrumen berjumlah 30 item. Terlebih dahulu instrumen tersebut diujicobakan kepada 27 siswa MI Bojongjati Pangandaran. Hasilnya dianalisis validitas dan reliabilitasnya. Dari 30 item tersebut, 15 item dinyatakan valid dan yang tidak valid berjumlah 15 . Kemudian ke-15 instrumen tersebut disebarkan ke 22 siswa kelas V MI Al-Misbah Bandung yang menjadi responden dalam penelitian ini. Angket yang disebarkan kepada responden dikembangkan dari indikator tanggapan Siswa Kelas V MI Al-Misbah Bandung pada mata pelajaran Ilmu Pengetahuan Sosial melalui model pembelajaran Kooperatif Tipe The Learning Cell yang diklasifikasikan kedalam 5 indikator, yaitu : (1) Siswa menyatakan ulang bacaan; (2) Siswa membuat pertanyaan; (3) Siswa berpasangan; (4) Siswa bergantian menjawab pertanyaan; (5) Guru memberi masukan atau penjelasan.

\section{HASIL DAN DISKUSI}

Hasil penelitian diperoleh dengan menghitung harga koefisien korelasi bertujuan untuk menentukan besarnya hubungan antara Tanggapan Siswa terhadap Model Kooperatif Tipe The Learning Cell pada Mata Pelajaran IPS Pokok Bahasan Proklamasi Kemerdekaan Republik Indonesia. Adapun langkah-langkahnya sebagai berikut.

1. Membuat tabel untuk mencari harga-harga yang diperlukan untuk pengujian Regresi Linier Sederhana serta analisis Koefisien Korelasi.

2. Karena data yang diperoleh menunjukan kedua variabel berdistribusi normal, maka terlebih dahulu dilakukan uji linearitas regresi dengan langkah-langkah sebagai berikut:

a) Menentukan persamaan regesi linier dengan rumus:

$$
\begin{aligned}
a & =\frac{\Sigma X^{2} \Sigma Y-\Sigma X \Sigma X Y}{N \Sigma X^{2}-(\Sigma X)^{2}} \\
& =\frac{(74313 \times 1341)-(1271 \times 78452)}{22 \times 74313-(1271)^{2}} \\
& =\frac{99653733-99712492}{1634886-1615441} \\
& =\frac{-58759}{19445} \\
& =-3,02 \\
b & =\frac{N \sum X Y-\Sigma X \Sigma Y}{N \Sigma X^{2}-(\Sigma X)^{2}} \\
& =\frac{(22 \times 78452)-(1271 \times 1341)}{22 \times 74313-(1271)^{2}} \\
& =\frac{1725944-1704411}{1634886-1615441} \\
& =\frac{21533}{19445} \\
& =1,11
\end{aligned}
$$
berikut:

Dengan demikian persamaan regresi linier sederhana $\mathrm{Y}$ atas $\mathrm{X}$ adalah sebagai

$$
\check{Y}=-3,02+1,11 X
$$


Tabel 1. Uji Regresi linier

\begin{tabular}{|c|c|c|c|c|c|}
\hline No & $\mathbf{X}$ & $\mathbf{Y}$ & $\mathbf{X}^{\mathbf{2}}$ & $\mathbf{Y}^{\mathbf{2}}$ & $\mathbf{X Y}$ \\
\hline 1 & 46 & 61 & 2116 & 3721 & 2806 \\
\hline 2 & 55 & 28 & 3025 & 784 & 1540 \\
\hline 3 & 64 & 67 & 4096 & 4489 & 4288 \\
\hline 4 & 56 & 50 & 3136 & 2500 & 2800 \\
\hline 5 & 65 & 72 & 4225 & 5184 & 4680 \\
\hline 6 & 60 & 72 & 3600 & 5184 & 4320 \\
\hline 7 & 61 & 67 & 3721 & 4489 & 4087 \\
\hline 8 & 62 & 83 & 3844 & 6889 & 5146 \\
\hline 9 & 61 & 72 & 3721 & 5184 & 4392 \\
\hline 10 & 66 & 67 & 4356 & 4489 & 4422 \\
\hline 11 & 53 & 56 & 2809 & 3136 & 2968 \\
\hline 12 & 57 & 67 & 3249 & 4489 & 3819 \\
\hline 13 & 61 & 78 & 3721 & 6084 & 4758 \\
\hline 14 & 49 & 67 & 2401 & 4489 & 3283 \\
\hline 15 & 58 & 62 & 3364 & 3844 & 3596 \\
\hline 16 & 47 & 44 & 2209 & 1936 & 2068 \\
\hline 17 & 49 & 44 & 2401 & 1936 & 2156 \\
\hline 18 & 55 & 56 & 3025 & 3136 & 3080 \\
\hline 19 & 53 & 44 & 2809 & 1936 & 2332 \\
\hline 20 & 62 & 67 & 3844 & 4489 & 4154 \\
\hline 21 & 71 & 67 & 5041 & 4489 & 4757 \\
\hline 22 & 60 & 50 & 3600 & 2500 & 3000 \\
\hline Jumlah & 1271 & 1341 & 74313 & 85377 & 78452 \\
\hline & & & & & \\
\hline
\end{tabular}

b) Menentukan Jumlah Kuadrat regresi a $\{\mathrm{JK}$ reg(a) $\}$, dengan rumus:

$$
\operatorname{JKreg}(a)=\frac{(\Sigma Y)^{2}}{n}=\frac{(1341)^{2}}{22}=\frac{1798281}{22}=81740,05
$$

c) Menentukan Jumlah Kuadrat regresi b terhadap a $\{\mathrm{JK}$ reg (b/a) $\}$, dengan rumus:

$$
\begin{aligned}
\operatorname{JKreg}(b / a) & =b\left\{\Sigma X Y-\frac{\Sigma X \Sigma Y}{n}\right\} \\
& =1,11\left\{78452-\frac{1271 \times 1341}{22}\right\} \\
& =1,11 \times\left\{78452-\frac{1704411}{22}\right\} \\
& =1,11 \times\{78452-77473,23\} \\
& =1,11 \times 978,77=1086,44
\end{aligned}
$$

d) Menentukan Jumlah Kuadrat residu (JKres), dengan rumus:

JKres $=\Sigma Y^{2}-J \operatorname{Kreg}(b / a)-J \operatorname{Kreg}(a)$

JKres $=85377-1086,44-81740,05=2550,52$

e) Menentukan Rata-rata Jumlah Kuadrat regresi a \{RJK reg(a)\}, dengan rumus: $\operatorname{RJKreg}(a)=\operatorname{JKreg}(a)=81740,05$

f) Menentukan Rata-rata Jumlah Kuadrat regresi b terhadap a $\{$ RJK reg(b/a) $\}$, dengan rumus:

RJKreg $(b / a)=J \operatorname{Kreg}(b / a)=1086,44$

g) Menentukan Rata-rata Jumlah kuadrat residu (RJKres), dengan rumus:

RJKres $=\frac{\text { JKres }}{n-2}=\frac{2550,52}{22-2}=127,53$

h) Mengurutkan data variabel $\mathrm{X}$ mulai dari skor terendah sampai tertinggi disertai pasangannya. 
Tabel 2. Pasangan Nilai Variabel X dan Y

\begin{tabular}{|c|c|c|c|c|}
\hline No & $\begin{array}{c}\text { Skor } \\
\text { Variabel X }\end{array}$ & Kelompok & $\begin{array}{c}\text { Skor } \\
\text { Variabel Y }\end{array}$ & $\mathbf{N}$ \\
\hline 1 & 46 & 1 & 61 & 1 \\
\hline 2 & 47 & 2 & 44 & 1 \\
\hline 3 & 49 & \multirow{2}{*}{3} & 44 & \multirow{2}{*}{2} \\
\hline 4 & 49 & & 67 & \\
\hline 5 & 53 & \multirow{2}{*}{4} & 44 & \multirow{2}{*}{2} \\
\hline 6 & 53 & & 56 & \\
\hline 7 & 55 & \multirow{2}{*}{5} & 28 & \multirow{2}{*}{2} \\
\hline 8 & 55 & & 56 & \\
\hline 9 & 56 & 6 & 50 & 1 \\
\hline 10 & 57 & 7 & 67 & 1 \\
\hline 11 & 58 & 8 & 61 & 1 \\
\hline 12 & 60 & \multirow{2}{*}{9} & 50 & \multirow{2}{*}{2} \\
\hline 13 & 60 & & 72 & \\
\hline 14 & 61 & \multirow{2}{*}{10} & 67 & \multirow{2}{*}{2} \\
\hline 15 & 61 & & 72 & \\
\hline 16 & 61 & 11 & 78 & 1 \\
\hline 17 & 62 & \multirow{2}{*}{12} & 67 & \multirow{2}{*}{2} \\
\hline 18 & 62 & & 83 & \\
\hline 19 & 64 & 13 & 67 & 1 \\
\hline 20 & 65 & 14 & 72 & 1 \\
\hline 21 & 66 & 15 & 67 & 1 \\
\hline 22 & 71 & 16 & 67 & 1 \\
\hline
\end{tabular}

i) Menentukan Jumlah Kuadrat Error $\left(\mathrm{JK}_{\mathrm{E}}\right)$ berdasarkan tabel diatas, dengan rumus:

$$
\begin{aligned}
& J K E= \Sigma\left\{\Sigma Y^{2}-\frac{(\Sigma Y)^{2}}{n}\right\} \\
& \mathrm{JKE}=\left\{61^{2}-\frac{(61)^{2}}{1}\right\}+\left\{44^{2}+-\frac{(44)^{2}}{1}\right\}+\left\{44^{2}+67^{2}-\frac{(44+67)^{2}}{2}\right\}+ \\
&\left\{44^{2}+56^{2}-\frac{(44+56)^{2}}{2}\right\}+\left\{28^{2}+56^{2}-\frac{(28+56)^{2}}{2}\right\}+\left\{50^{2}-\frac{(50)^{2}}{1}\right\}+ \\
&\left\{67^{2}-\frac{(67)^{2}}{1}\right\}\left\{+\left\{61^{2}-\frac{(61)^{2}}{1}\right\}+\left\{50^{2}+72^{2}-\frac{(50+72)^{2}}{2}\right\}+\right. \\
&\left\{67^{2}+72^{2}-\frac{(67+72)^{2}}{2}\right\}+\left\{78^{2}-\frac{(78)^{2}}{1}\right\}+ \\
&\left\{67^{2}+83^{2}-\frac{(67+83)^{2}}{2}\right\}+\left\{67^{2}-\frac{(67)^{2}}{1}\right\}+\left\{72^{2}-\frac{(72)^{2}}{1}\right\}+\left\{67^{2}-\frac{(67)^{2}}{1}\right\}+ \\
&\left\{67^{2}-\frac{(67)^{2}}{1}\right\} \\
&=0+0+264,5+72+392+0+0+0+242+12,5+0+128+0+0+0+0=1111
\end{aligned}
$$

j) Menentukan Jumlah Kuadrat Tidak Cocok $\left(\mathrm{JK}_{\mathrm{TC}}\right)$, dengan rumus:

$$
J K T C=J K r e s-J K E=2553,08-1111=1442,08
$$

k) Menentukan Rata-rata Jumlah Kuadrat Tidak Cocok $\left(\mathrm{RJK}_{\mathrm{TC}}\right)$, dengan rumus:

$$
\begin{aligned}
\text { RJKTC } & =\frac{J K T C}{k-2} \\
& =\frac{1442,08}{16-2} \\
& \frac{1442,08}{14} \\
& =103,01
\end{aligned}
$$

1) Menentukan Rata-rata Jumlah Kuadrat Error $\left(\mathrm{RJK}_{\mathrm{E}}\right)$, dengan rumus: 


$$
\begin{aligned}
R J K E & =\frac{J K E}{n-k} \\
& =\frac{1111}{22-16} \\
& =\frac{1111}{6} \\
& =185,17
\end{aligned}
$$

m) Menentukan nilai $\mathrm{F}$ hitung, dengan rumus:

$$
\begin{aligned}
\text { Fhitung } & =\frac{\text { RJKTC }}{\text { RJKE }} \\
& =\frac{103,01}{185,17} \\
& =0,56
\end{aligned}
$$

n) Menentukan $\mathrm{F}$ tabel

Untuk mengetahui nilai $\mathrm{F}$ tabel, maka terlebih dahulu menentukan derajat kebebasan pembilang dan derajat kebebasan penyebut pada taraf signifikansi $5 \%$.

$\mathrm{db}$ pembilang $=\mathrm{k}-2=16-2=14$

$\mathrm{db}$ penyebut $=\mathrm{n}-\mathrm{k}=22-16=6$

Jika dilihat pada daftar $\mathrm{F}$ tabel dengan taraf signifikansi 5\% dengan db $=14 / 6$ maka diperoleh nilai $\mathrm{F}$ tabel sebesar 3,96.

o) Menentukan kriteria pengambilan keputusan atau kriteria uji linieritas dengan ketentuan sebagai berikut:

Jika $F_{\text {hitung }}>F_{\text {tabel }}$ berarti regresi $Y$ terhadap $X$, maka TIDAK LINIER;

Jika $F_{\text {hitung }}<\mathrm{F}_{\text {tabel }}$ berarti regresi $\mathrm{Y}$ terhadap X, maka LINIER.

p) Membandingkan nilai $\mathrm{F}$ hitung dengan $\mathrm{F}$ tabel untuk ditarik kesimpulan.

Setelah melalaui beberapa tahap perhitungan regresi linier sederhana, maka

\begin{tabular}{|c|c|c|c|c|c|}
\hline Sumber Variasi & $\mathrm{Db}$ & $\mathrm{JK}$ & RJK & F hitung & F tabel \\
\hline Total & 22 & 85377 & - & 0,56 & 3.96 \\
\hline Regresi (a) & 1 & 81740,05 & 81740,05 & \multirow{4}{*}{\multicolumn{2}{|c|}{$\begin{array}{l}\text { Kesimpulan : Karena } \\
\text { F hitung }<\text { F tabel atau } \\
0,56<3,96 \text {, maka dapat } \\
\text { disimpulkan bahwa } \\
\text { regresi Y atas X linier. }\end{array}$}} \\
\hline Regresi (b/a) & 1 & 1086,44 & 1086,44 & & \\
\hline Tidak Cocok (TC) & 14 & 1442,08 & 103,01 & & \\
\hline Kesalahan (Error) & 6 & 1111 & 185,17 & & \\
\hline
\end{tabular}
dengan mengetahui hasil dari $\mathrm{F}$ hitung dan $\mathrm{F}$ tabel, ternyata dalam penelitian ini $F_{\text {hitung }}<\mathrm{F}_{\text {tabel }}$ dimana $\mathrm{F}$ hitung sebesar 0,56 dan $\mathrm{F}$ tabel sebesar 3,96 sehingga dapat disimpulkan bahwa regresi Y terhadap X LINIER.

Untuk lebih jelasnya berikut ini disajikan tebel ringkasan Anava untuk regresi dengan persamaan $\mathrm{Y}=-3,02+1,11 \mathrm{X}$ sebagai berikut.

Tabel 3. Ringkasan Anava untuk Regresi $\mathrm{Y}=-3,02+1,11 \mathrm{X}$

3. Menghitung Koefesien Korelasi

Berdasarkan perhitungan di atas, kedua variabel berdistribusi normal dan regresi linier. Dengan demikian, dalam proses perhitungan, nilai koefesien korelasinya menggunakan rumus korelasi product moment.

$$
r_{x y}=\frac{N \Sigma X i Y i-(\Sigma X i)(\Sigma Y i)}{\sqrt{\left\{N \Sigma X i^{2}-(\Sigma X i)^{2}\right\}\left\{N \Sigma Y i^{2}-(\Sigma Y i)^{2}\right\}}}
$$




$$
\begin{aligned}
& =\frac{22 \cdot 78452-(1271)(1341)}{\sqrt{\{22.74313-1615441\}\{22.85377-1798281\}}} \\
& =\frac{1725944-1704411}{\sqrt{\{1634886-1615441\}\{1878294-1798281\}}} \\
& =\frac{21533}{\sqrt{\{19445\}\{80013\}}} \\
& =\frac{21533}{\sqrt{1555852785}} \\
& =\frac{21533}{39444,30} \\
& =0,55
\end{aligned}
$$

Berdasarkan perhitungan diatas diperoleh nilai $r_{x y}=0,55$. Harga korelasi ini berada pada rentang $0,40-0,60=$ Sedang, artinya antara variabel $\mathrm{X}$ dengan variabel $\mathrm{Y}$ korelasinya sedang.

4. Menguji signifikansi korelasi dengan langkah-langkah sebagai berikut:

a) Menentukan nilai $t_{\text {hitung }}$ dengan rumus:

$$
\begin{aligned}
t & =\frac{r \sqrt{n-2}}{\sqrt{1-r^{2}}} \\
& =\frac{0,55 \sqrt{22-2}}{\sqrt{1-0,55^{2}}} \\
& =\frac{0,55 \sqrt{20}}{\sqrt{1-0,30}} \\
& =\frac{0,55(4,47)}{\sqrt{0,70}} \\
& =\frac{2,44}{0,84} \\
& =2,914
\end{aligned}
$$

b) Menentukan tabel pada taraf signifikansi 5\% dengan ketentuan:

$$
\begin{aligned}
\mathrm{dk} & =\mathrm{n}-2 \\
& =22-2 \\
& =20
\end{aligned}
$$

c) Mencari nilai tabel dengan $\mathrm{dk}=20$ dan taraf signifikansi $5 \%=2,086$

d) Pengujian hipotesis dengan ketentuan:

Berdasarkan hasil perhitungan diatas, $t_{\text {hitung }}=2,914$ dan $t_{\text {tabel }}=2,086$. Dengan demikian harga $t_{\text {hitung }}>t_{\text {tabel }}$ atau 2,914 $>2,086$. Dalam keadaan demikian, maka hipotesis nol (Ho) ditolak dan hipotesis alternatif (Ha) diterima. Dengan kata lain terdapat hubungan positif yang signifikan antara tanggapan siswa terhadap model pembelajaran kooperatif tipe the learning cell hubungannya dengan hasil belajar siswa pada mata pelajaran IPS pokok bahasan proklamasi kemerdekaan Republik Indonesia.

5. Uji pengaruh antara variabel $\mathrm{X}$ dengan variabel $\mathrm{Y}$, dengan rumus sebagai berikut:

a) Menentukan derajat tidak adanya korelasi, dengan rumus:

$$
\begin{aligned}
& K=\sqrt{1-r^{2}} \\
& =\sqrt{1-0,55^{2}} \\
& =\sqrt{1-0,30}
\end{aligned}
$$




$$
\begin{aligned}
& =\sqrt{0,70} \\
& =0,84
\end{aligned}
$$

b) Menghitung tinggi rendahnya pengaruh antara kedua variabel, menggunakan rumus:

$$
\begin{aligned}
& \mathrm{E}=100(1-\mathrm{K}) \\
& \mathrm{E}=100(1-\mathrm{K}) \\
& =100(1-0,84) \\
& =100(0,16) \\
& =16
\end{aligned}
$$

Berdasarkan perhitungan di atas, dapat diketahui besarnya pengaruh variabel $\mathrm{X}$ (Tanggapan Siswa Terhadap Model Kooperatif Tipe The Learning Cell) terhadap variabel Y (Hasil Belajar Mata Pelajaran IPS Pokok Bahasan Proklamasi Kemerdekaan Republik Indonesia) yaitu sebesar $16 \%$, dan sisanya sebesar $84 \%$ dipengaruhi oleh faktor lainnya.

\section{SIMPULAN}

Berdasarkan hasil analisis data tentang Tanggapan Siswa Terhadap Model Pembelajaran Kooperatif Tipe The Learning Cell Hubungannya dengan Hasil Belajar Mereka pada Mata Pelajaran IPS Pokok Bahasan Proklamasi Kemerdekaan Republik Indonesia, dapat ditarik kesimpulan sebagai berikut:

1. Realitas tanggapan siswa terhadap model pembelajaran kooperatif tipe The Learning Cell termasuk kedalam kategori tinggi. Hal ini ditunjukkan oleh nilai rata-rata siswa mencapai3,97. Angka tersebut berada pada interval 3,40-4,19.

2. Realitas hasil belajar mereka pada mata pelajaran IPS pokok bahasan proklamasi kemerdekaan Republik Indonesia dalam kategori cukup. Hal ini ditunjukkan oleh nilai rata-rata mencapai 65,54. Angka tersebut berada pada interval 60 - 69.

3. Hasil penghitungan korelasi antara tanggapan siswa terhadap model pembelajaran kooperatif tipe The Learning Cell dengan hasil belajar mereka pada mata pelajaran IPS pokok bahasan proklamasi kemerdekaan Republik Indonesia diperoleh koefisien korelasi sebesar 0,55 . Nilai ini berada pada rentang 0,40-0,60, artinya tergolong pada kategori sedang. Hasil uji hipotesis diperoleh harga $\mathrm{t}_{\text {hitung }}$ sebesar 2,914 lebih besar dari pada $\mathrm{t}_{\text {table }}$ 2,086 pada taraf signifikasi 5\%. Dengan demikian dapat disimpulkan bahwa Ha diterima dan Ho ditolak, dalam artian bahwa terdapat hubungan yang signifikan antara variabel X dengan variabel Y. Adapun derajat pengaruh variabel X terhadap variabel Y sebesar $16 \%$. Angka ini menunjukkan bahwa $84 \%$ hasil belajar mereka kelasV MI AL-Misbah Bandung dipengaruhi oleh faktor lain.

\section{DAFTAR PUSTAKA}

Muhibbin Syah. 2004. Psikologi Pendidikan dengan Pendekatan Baru. Bandung: Remaja Rosda karya.

Suprijono, A. (2010). Cooperative Learning Teori \& Aplikasi Paikem. Yogyakarta: Pustaka Belajar.

Suryana, Y. \& Priatna. T. (2009). Metode Penelitian Pendidikan. Bandung: Sahifa.

Sutikno, S. (2009). Belajar dan Pembelajaran. Bandung: Prospect. 